\title{
LAWS OF LANGUAGE AND LEGAL LANGUAGE: A STUDY OF LEGAL LANGUAGE IN SOME INDONESIAN REGULATIONS
}

\author{
Shidarta \\ Business Law Department, Faculty of Humanities, Bina Nusantara University \\ Jln. Kemanggisan Ilir III No. 45, Palmerah, DKI Jakarta 11480, Indonesia \\ shidarta@binus.edu
}

\begin{abstract}
Legal language must follow the laws of language (grammar) that widely known and commonly used by the public, including groups of the scientist. Legal language on the other hand also recognizes specific terminologies. These terminologies were introduced by jurists or by legislative power holders. Accordingly, legal language became the product of legal doctrines or political decisions. The problems arose when a number of compositions and legal terms turned out to be elusive, convoluted, and ambiguous due to the pattern of writing that was once done and because of certain considerations. This article proposed reviewing the factors that result in problems. The author presented a solution to observe using hermeneutic methods of law and legal reasoning. The author argued that the text of the law was not neutral since it was trapped not only by the laws of language but also by the perspective of the interpreters as they believed such a perspective was based on the guidance of legal science. By using legal hermeneutics can be checked the depth of the meaning of the law; while over the legal reasoning can be seen its rationale according to legal science.
\end{abstract}

Keywords: laws of language, legal language, legal hermeneutics, legal reasoning

\section{INTRODUCTION}

The legal language must obey the laws of language. This is a jargon that must be accepted, considering that every language has its own rules. Those rules refer to the grammar, especially the syntactic, semantic, and pragmatic aspects (Morris, 1970; Danet, 1980). Thus, legal language must follow all the rules. The law is a system of legal relations which condition social action to serve the common interest. The law is a product of social processes which determine society's common interest and which organize the making and application of law (Allott, 1999). But, a law is formally considered as a political product. As stated by the legal positivists, the law is a command of lawgivers. Aristotle compares the lawgiver to a craftsman who turns natural material (the exigencies of nature and natural human impulses) into a finished product (a legal order). Such persons are totally trustworthy and incorruptible; they do not require safeguards against the abuse of power (Swiffen, 2011; Keith, Tate, \& Poe, 2009).

Perhaps the most extreme version of this approach is not surprisingly rendered from a civil law perspective, but it comes from Montesquieu who said that judicial judgments are to be "fixed to such a degree that they are never anything but a precise text of the law". Judges are "only the mouth that pronounces the words of the law, inanimate beings who can moderate neither its force nor its rigor" (Terrell, 2012). This perspective is taken to prevent any differences in the legal meaning. The law wants to have uniformity of meaning for everyone. Only in this way the law can achieve legal certainty (Posner, 1987). 
Since laws are made by political authorities, the legal language is also loaded with political contents and created for the sake of the people. They believe that all authorized rulers are always of good will to legislate and enforce the law. In fact, they are not. There are numerous occasions that legislation is no longer neutral. Analyses of this partiality may first be seen from the use of the language. Some indicators of this can be traced from the legal language as it is used in the language of the legislation. The indicators can be viewed in four factors that arise related to legal concepts and legal propositions. Such problems can be tracked by using two instruments, namely legal hermeneutics, and legal reasoning. These are the things that will be addressed in this paper.

\section{METHODS}

This article departs from the study of some regulations randomly held. The regulations are analyzed by looking for examples of problematic language in it. This research can be considered as a text analysis. The analysis is conducted on the factors that characterize the problem of legal language as contained in this law. Hermeneutics and legal reasoning approach specifically are raised in this study to demonstrate that the problems can be resolved with a text not out of the laws of language.

To some extent, this research can be regarded as hermeneutic research. It is always about understanding, about what it means to be in the world in a particular way. Truth, at least the truth about being human and human practice, is also tricky because it is located in time and place. It can and does change (and stay the same) over time and between places. The hermeneutic truth is plural, not singular (Moules et al., 2014). In many ways, the work of hermeneutics as a research approach is somewhat intuitive, but we also believe it is something that can be taught, learned, and definitely practiced (Moules \& McCaffrey, 2015).

The choice of the method is considered appropriate to examine the issue of language in legal texts. There are numerous studies applying hermeneutics method, and many shades of methods are utilized. One of them is philosophical hermeneutics. According to Mootz (2009), philosophical hermeneutics provides an ontological account of the social nature of understanding that girds rhetorical activity. Rhetorical analysis moves from this ontology to political engagement, revealing the entwinement of theory and practice.

\section{RESULTS AND DISCUSSIONS}

The problems that want to be raised in this paper is about the factors that characterize the relationship between legal language and the laws of language, as well as the mechanism that can be taken to overcome the problems that arise from the relationship. The frame of thinking constructed in this analysis can be described in Figure 1.

The concept is a generalization of the facts. When the concept is to be communicated, then it needs to be given a name, i.e. terminology. Likewise, some legal concepts have something to do with legal terminologies. There are numerous legal terminologies that are made by the legislators. Of course, such terminologies are made with regards to the provisions of the laws of language. For example, in Article 1 point 3 of Law Number 13 The year 2003 on Manpower, found the term pekerja/buruh (labor) meaning every person who works for a wage or other forms of remuneration. The term also appears in Article 1 point (17) regarding serikat pekerja/serikat buruh (labor union). These two terms are clearly the same meaning. However, why should legislators use them together? When viewed from in the establishment of this law, it can be immediately known that it happened 
because at that moment there was a tension between labor unions that were using different names. Serikat pekerja did not want to adjust the name becoming serikat buruh, and vice versa. In the end, the legislators tried to take the middle road by adopting both names and determining the term serikat pekerja/serikat buruh. This shows the inefficiency of the use of words. Another example can be shown when the Law Number 5 The year 1999 on Monopoly Practices and Unfair Competition uses the term persaingan usaha tidak sehat (unhealthy business competition) which is actually drawn from the word "unfair competition" in English. In the textbooks of law in Indonesia, actually, there has been more common to employ the term persaingan curang (unfair competition) rather than persaingan usaha tidak sehat (unhealthy competition) (Shidarta, 2013). Of course, the choice of these words has a particular reason, but sometimes it is not quite logical.

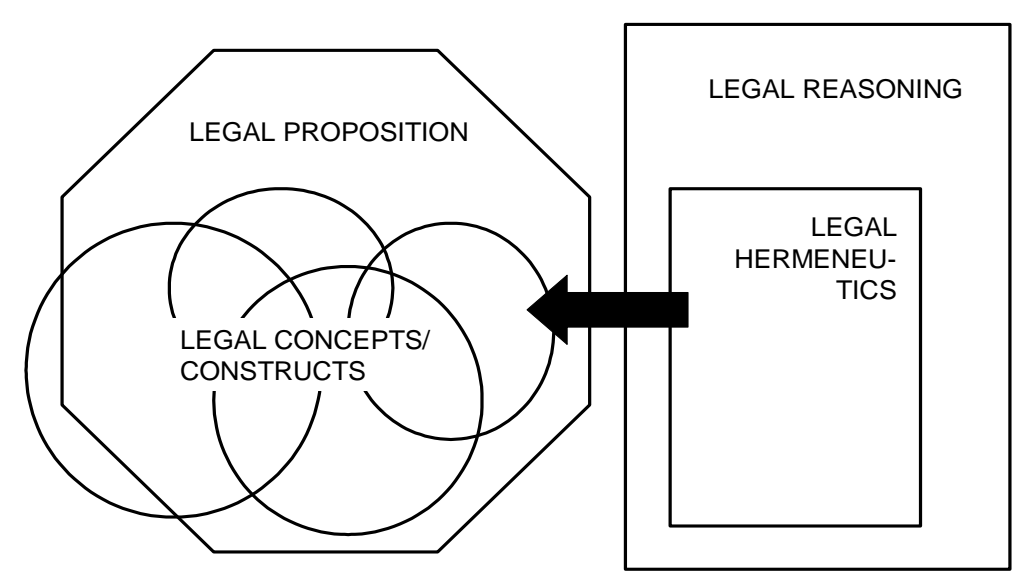

Figure 1 The Relationship among Legal Propositions,

Legal Concept/Construct, Legal Hermeneutics, and Legal Reasoning

In some regulations, the key concepts should be defined. There are many types of definitions known in logics, but in general, can be divided into connotative and denotative definitions. The connotative definition refers to the characteristics contained in the definiendum. These characteristics are described in Definiens, which is subject to the rule definitio per genus proximum et differentias specificas. On the other hand, there is the denotative definition that formulated by direct appointment to the members who meet those characteristics. For example, the word "minister" in the legislation is not defined as a cabinet member in charge of helping the president to manage the government in a particular portfolio. The definition in the legislation is much more defined denotatively. For instance, in Article 1 point 33 of Law Number 13 The year 2003, it is said that the minister is the minister responsible for labor affairs. Of course, this definition does not qualify as a good connotative definition, but quite adequate for a legal definition. This definition is closer than the definition of a connotative denotative definition. According to laws of language, a definition that starts with the words "minister is the minister" would have violated the principles of making a satisfactory definition. However, if it is interpreted that the definitions in the law are not always figuratively, but also denotative, hence the choice of the way to eventually becomes acceptable. If we look more closely, the concepts in the law of most of it are not easy to find a denotation. This occurs because legislators actually compelled to make constructs and constructed concepts generally require connotative definitions. The keywords in the legislation, which in the Indonesian legal language called pranata hukum, generally are given with connotative definitions, while the so-called Lembaga Hukum that is given with denotative definitions. In the laws of language as known in Indonesian grammar, a constructed formulation is done by giving the suffix "ke" and the suffix "an". For example, the word 
kemanusiaan (humanity) is the constructed result of manusia (Human). If there is a word kemanusiaan appearing in the keywords to be defined, the definition is done in the connotative and not denotative.

The meaning of a concept, of course, is not obliged to always rely on the definition given by the law. Habits in the community, court decisions, and legal doctrines can enrich the legal definitions set forth in Article 1 of each law. For instance, is one element of the action "theft" is "taking the property of others" (Article 363 of the Indonesian Penal Code). This element is not defined by law, but the legal doctrines and decisions of the judges and this element are defined as "moving goods from one place to another". This definition is generally recognized in the community of legal experts, so it is considered no longer need to be defined specifically in the legislation.

Legal terms cannot be changed just like the change in society. The legal terms may be sourced from areas regulated by such laws, for example in the fields of medicine, engineering, and agriculture, which each area can contribute its specific terms. Once these terms are admitted into the legislation, then the terms are instantly transformed into legal terms. People might agree to the terms to be their new terms in everyday language, but they can also reject them. If rejected, then the terms have a very limited use, merely used in the legal language. For example, Law Number 8 The year 2015 on Local Election introduces the term calon peseorangan (personal candidate), but people (also mass media) prefer to call it calon independen (independent candidate).

In law, concepts or constructs do not stand alone. Concepts that have given meaning in legal language should be linked to each other. These relationships generate propositions. In a very limited scope, the proposition of law is the principle of law. So, every legal principle must consist of more than one concept/construction law. For example, the legal principle of lex specialis is a proposition that connects at least two concepts, namely the concept of lex and the concept of legal generalists. This relationship has the capacity to explain the concept. The concept is perhaps one higher than the other concepts. However, it is not only this. This relationship is allowed to predict which of the two concepts that should be given priority in case of conflict between the two. Sometimes these relationships cannot be detected because the concept terminologies are not stated explicitly. It is an example of legality principle. This principle wears a concept name. Whereas, in the name of the concept of legality is already contained concepts such as lex scripta, lex certa and lex stricta (Hallevy, 2010). Legislation that includes the principle of legality is never mentioned the existence of these concepts, but the doctrine introduces them. Even the word legality itself is not included in Article 1 paragraph (1) of the Indonesian Penal Code. However, anyone who has studied law will know that in the article is the principle of legality.

Thus the legal language should exert its ability to be in a position to give an explanation as to what the relationship between the concepts that is intertwined. As well as what the meaning of which that can be generated. There should be clear limits to restrict the relationship concepts. Clarity was not dealt with only to the legislators, but above all, to the general public because they are the subject of the legislation. This is the place where the role of the language laws. People understand the legal language does not belong to the standpoint of the law but from the perspective of the laws of language. Legislators sometimes are not aware that the actual legal principle cannot simply be born through the political process. The principle of the law is born through the scientific process, in this case through the study of the philosophy of law and legal theory. Fauerbach who created the principle of legality is not a legislator. He is a legal theorist and legal philosopher who published his account of the principle of legality in the textbook that he wrote and later cited by many legal experts. Radbruch (1999), for example, when he says that the facts repeatedly have the normative force (die normative Kraft des Faktischen), never realizing that his words could enrich legal principles. It seems the legislators in Indonesia apparently are not quite aware of this situation, so that in many regulations, the legal principles may be created very easily. For instance, in Law Number 12 The year 2011 on the Establishment of Regulations, there are seven legal principles that must be considered, which are called as the foundation of legislation. The principles as stated in Article 5 include; (1) the clarity of 
purpose, (2) the right institutions or officials, (3) the suitability among the forms, the hierarchy, and the contents of law, (4) can be carried out, (5) efficiency and effectiveness, (6) clear formulation, and (7) transparency. Then in Article 6 is added again that the substance should be reflected in the principles of (1) protection, (2) humanities, (3) nationality, (4) kinships, (5) the Indonesian hood, (6) unity in diversity, (7) justice, (8) equal position in law and government, (9) the legal order and legal certainty, and/or (10) balance, accord, and harmony.

Law Number 12 the Year 2011 is not careful enough to make a distinction between legal principles and requirements of the law. The provisions of Article 5 of that law are more referring to the requirements of legal principles. Impressed by the legislators that include various types of legal concepts and propositions of law which are later claimed as a principle of law. They do not create a mapping how these concepts relate to each other, are concepts that overlap, where propositions should be placed as a supra-principles, fundamental principles and secondary principles, and so on. So, principles such as stocked up without the arrangement. Things like this do not bring optimum benefits to the legislature for the principles of law that are too loose like this do not get a high application rate.

When a concept and proposition of law is contained in the legislation, the legal meaning of language-related concepts and propositions it being open. Legislators can only assume that they have locked the meaning of the concept and proposition it as tightly as possible in order to avoid ambiguity, vagueness, and value openness of meaning. Though the meaning of concepts and propositions coverage is no longer possible becomes verified by the legislators. So, it is right when hermeneutics legal experts say, the person who formulated the first meaning of the rule is merely the primary reader what he has made. People who become future readers have the freedom to redefine the concepts and propositions. Legal Hermeneutics is the theory used to interpret in the legal language. Therefore, the legal language refers to the validity of the norm. Then there is always a moral message to be built in every formulation of the norm. The formulation of this norm is a proposition consisting of interconnected legal concepts.

The semiotics of law as taught by Roland Barthes may be a bid to understand what the nature of the meaning behind the formulation of legal norms. Barthes demonstrates that the world we perceive is one not of facts, but rather of signs about facts which we encode and decode ceaselessly from signifying systems to signifying system (Waugh, 2006; Booryazadeh, 2014). For example, Article 284 Paragraph (1) of the Penal Code states threatened with a minimum of nine months when a man is married and committing adultery, whereas Article 27 of the Civil Code applies to him. This section continues with the words; a woman who has been married to commit adultery. This article contains a moral message that men and women who commit adultery should have been tied to marriage. So, adultery equally bachelors cannot be categorized as perpetrators of the act of adultery. The definition of such fornication and adultery is clearly contrary to the notion of the public. People understand adultery as an act of intercourse by couples who are not bound together by marriage. No matter what their status are already married to someone or not. Legal language will impose the meaning that adultery should be within the limits of such. Society may give a different meaning is far more extensive, but these limits will be guarded by law until a new decision is to amend it. Through hermeneutics, the structure of the rules can be defined more comprehensively. There is not any assurance that hermeneutic can bring an objective meaning, but minimal inter-subjective meaning. Hermeneutics can build structures that depart from the norm concepts, constructs, and propositions follow exactly what it is said in the text. This interpretation is generally called grammatical interpretation. Interestingly, this interpretation has not been completed according to hermeneutics. This interpretation should be reached the level of critical reflection, i.e., up to values. It is a philosophical interpretation. To that end, semiotics method will be very useful, so that the dimensions of syntactic, semantic, and pragmatic.

If a structure of rules is already done through the instrument of hermeneutics, the structure of this requires a context as a tool for testing. This context is supplied by a concrete case. Here we see 
that every text of the law is not going to be active (in flux) if there are no concrete cases that occur. Concrete case is an activator for the law. Up here is impressed that the legislation always comes first before the concrete case. The principle of legality also wants the law applicable prospective, not retroactive. However, the text of legal norms is not made in a vacuum condition. This text is inspired by a lot of contexts that precede the formation of positive law. If a concrete event occurs after the enactment of positive law, then that event has the opportunity to be associated with the positive law. Legal Dogmatics teaches us how to link them with legal reasoning in which syllogism is one its main methods to practice. The syllogism is a very classical way in legal reasoning, but it still works.

Syllogism starts from the major premise. The premise is available from the structure of the rules that have been interpreted correctly. At the very least, the assumption is stated thus. This structure can be applied to the minor premise. The second premise is obtained from a concrete case. The conclusion that is coming from the two premises is its synthesis. For example, if the provision says, "Every person who takes the goods, partly or wholly owned by another person, with intent to held unlawfully, will be threatened for theft, with a maximum imprisonment of five years or with at most sixty rupiahs" (Article 362 of the Penal Code). This article will wait until there are people who meet the criteria of taking goods partly or wholly owned by someone else, and so on. In a syllogism, every element from the norm in Article 362 is examined one by one. The word "everyone" will be associated with the subject of the law, regardless whoever that person(s). The word "takes the goods" will be linked with the action moving a thing (i.e. wallet, books, television, or any object of law). How to connect this could have been easy, but it can also not be very easy. It will not be easy if the textual (grammatical) meaning of the text will be too narrow or too broad in scope after it is connected to the context of the concrete event. Here again, hermeneutics becomes important to request assistance. If it is known that there is scope within the meaning of the text is too constricted, then the interpreter's task to expand the meaning of it. This expansion helps legal language that could be contextually applicable to answer the question of a legal event. Formerly person of goods must be tangible objects, which can be presented as evidence in court. When there is a theft of electricity, then the question is whether the electricity is also stuff? Through syllogism judge eventually turns off that items could also be expanded to include energy. Every energy is the goods. Electricity is energy. So, electricity is the goods.

Thus, the syllogism is another very useful instrument to test the validity of legal language. Syllogism does not come here from distant places. It comes from the laws of language. Thus it is true that legal language should not be out of the realm of laws of language.

\section{CONCLUSIONS}

Legal language is distinctive because it is built through political decisions. It can be traced from the choice of words that used to be legal terminologies. Concepts and propositions of law are woven as a single entity in the legislation to be applied to the community. Thus, the concepts and propositions of law must be understood according to the laws of language.

Concepts and constructs are the modalities in the formation of the legal proposition. Every proposition must consist of more than one concept or construct. The problem has existed for the first time when a concept or construct will be named as a legal terminology. Non-legal factors, especially political one, have a very strong influence in choosing such a legal term. The next major issue occurs when a concept or construct that will be defined. The inability of legislators to produce a precise definition will affect the meaning presented in legal texts. There is a way which offers opportunities to save the meaning of misinterpretation. This method is introduced by legal hermeneutics, which can be seen as digging the deepest meaning. The next way is the legal reasoning, which is mainly done by connecting the text that has been given meaning hermeneutically, by the context. This engagement 
process is largely done by the method of syllogism. In other words, the laws of language always provide instruments to assess whether the legal language has been able to function well to give a relatively precise meaning in settling a certain legal context. The legal language would be unable to escape from the laws of language.

The author believes that the study of a number of regulations in this paper shows that there are still a lot of fundamental weaknesses in the use of legal language in Indonesian legislation. This weakness must be addressed, among others, by mastering the appropriate methods of legal reasoning, in which the substance of legal hermeneutics is included. Further research is necessary to provide certain legal instruments needed to improve the legal reasoning quality of Indonesian legal apparatus as shown in the legal documents, such as in regulations and court decisions.

\section{REFERENCES}

Allott, P. (1999). The concept of international law. European Journal of International law, 10(1), 3150.

Booryazadeh, S. A. (2014). Barthes' irreversible codes: an intertextual reading of James Joyce's 'Araby'. International Journal of Applied Linguistics and English Literature, 3(1), 137-141.

Danet, B. (1980). Language in the legal process. Law and Society Review, 14(3), 445-564.

Hallevy, G. (2010). A modern treatise on the principle of legality in criminal law. Heidelberg: Springer.

Keith, L. C., Tate, C. N., \& Poe, S. C. (2009). Is the Law A Mere Parchment Barrier to Human Rights Abuse? The Journal of Politics, 71(2), 644-660.

Mootz, F. J. (2009). On philosophy in American law. Cambridge: Cambridge University Press.

Moules, N. J., Field, J. C., McCaffrey, G. P., Laing, C. M. (2014). Conducting hermeneutic research. Journal of Applied Hermeneutics, 1 - 13. Retrieved from http://jah.journalhosting.ucalgary.ca/jah/index.php/jah/article/view/66/pdf.

Moules, N. J., \& McCaffrey, G. (2015). Catching hermeneutics in the act. Journal of Applied Hermeneutics, 1 - 4.

Morris, C.W. (1970). Foundations of the theory of signs. Chicago: Chicago University Press.

Posner, R. A. (1987). Legal formalism, legal realism, and the interpretation of statutes and the constitution. Case Western Reserve Law Review, 37(2), 179 - 794.

Radbruch, G. (1999). Rechtsphilosophie-selected and rearranged excerpts, English translation. In R. Dreier \& Stanley L. Paulson (Eds). Heidelberg: C.F. Mueller.

Shidarta (2013, January 20). Catatan seputar hukum persaingan usaha. Retrieved December $2^{\text {nd }}, 2017$ from http://business-law.binus.ac.id/2013/01/20/catatan-seputar-hukum-persaingan-usaha/

Swiffen, A. (2011). Law without a lawgiver: legal authority after sovereignty. Journal of Law, Culture and the Humanities, 7(1) $66-80$. 
Terrell, T.P. (2012). The art of legal reasoning and the angst of judging: of balls, strikes, and moments of truth. Journal of Law \& Social Policy, 8(11), 35 - 88.

Waugh, P. (2006). Literary theory and criticism: an Oxford guide. New York: Oxford University Press. 